\title{
Feasibility of Quarry Dust to Replace River Sand as Fine Aggregate of Concrete
}

\author{
R W C N Rajapaksha and H P Sooriyaarachchi
}

\begin{abstract}
High cost and scarcity of river sand is one of the main problem faced by construction industry today. Use of substitutions like offshore sand in particular to replace river sand is on the rise. Quarry dust is another alternative for river sand. However, full replacement of river sand with quarry dust is viewed with scepticism. Possible loss of workability and increase shrinkage is sighted against use of quarry dust as fine aggregate in concrete. In this study the properties of concrete with quarry dust as fine aggregate is studied to find out its suitability to replace river sand in structural concrete. Furthermore, use of fly ash with $30 \%$ of cement replaced by fly ash is explored as means of increasing the performance of the quarry dust mixes. Quarry dust concrete at the tested water cement ratio is found to have higher compressive strength compared to sand mixes. However, use of quarry has increased the required amount of water in the mix to achieve the design slump. It is also found that the quarry dust mixes has higher shrinkage strain compared to sand mixes. Use of fly ash in quarry dust mixes is found helpful in reducing the shrinkage of quarry dust concrete. Results indicate that quarry dust can be effectively used to replace sand and fly ash can improve the performance of concrete with quarry dust as fine aggregate.
\end{abstract}

Keywords: Concrete, Fine aggregate, Quarry dust, River sand, Compressive strength, Shrinkage, Workability.

\section{Introduction}

Concrete is one of the most widely used building materials in construction. It is a composite building material made of cement/binder and aggregates. Aggregates used consist of fine and coarse aggregate. Coarse aggregate used in Sri Lanka is of the geological name Gneisses and it is normally used in the crushed form. River sand is the main fine aggregate used in Sri Lanka. Scarcity and restriction on sand mining has increased the price of sand in the recent times and therefore the cost of concrete. As an alternative to river sand, offshore sand and different kinds of artificial aggregates have been introduced from time to time. Various proportions of quarry dust have also been used as partial replacement of river sand. However, there is a reluctance to use quarry dust as $100 \%$ replacement of river sand. Quarry dust can be described as the residue or tailing material after the extraction and processing of rocks and that forms fine particles less than $4.75 \mathrm{~mm}$. Quarry dust constitutes $20-25 \%$ of the output of rubble crushing (Information gathered form the quarry owners).

Smooth round shape of river sand makes bond between the cement paste and the aggregate relatively weak. However, due to sperical shape of the river sand (surface area to volume of sand is small) and relatively low percentage of voids
(Maximum percentage of voids in river sand ranges from 32 33 percent [1][2]) less cement paste is required to make good concrete. As oppose to smooth granular nature of river sand, quarry dust has rough surface textures and angular shape due to crush nature of the aggregate. Rough surface texture provide better interlocking and good bond between the cement paste and the aggregate. Maximum percentage of voids in quarry dust ranges from $38-40 \%$ [1][2]. Due to angular nature of the aggregate (surface area to volume ratio of quarry dust is high) and the relatively high void ratio more cement paste is required with quarry dust to make good concrete. All the above reason make quarry dust quite a different material to river sand that require comprehensive study. Possible reduction in compressive strength due to lose packing of aggregate, reduction in workability and the increase of shrinkage are the major concerns of using quarry dust in concrete. However none of the above has been found experimentally. On the contrary, the use of

R W C N Rajapaksc, is a graduate engineer of University of Ruhuna

Eng. (Dr.) H.P. Sooriyaarachchi, C. Eng., MIE (Sri Lanka), B.Sc. Eng. (Moratuwa), M.Eng. (Tokyo), PhD. (Shefficld), Senior Lecturer in Civil and Environmental Enginecring, Faculty of Engittering, University of Ruhuna, Hapugala, Galle. 
crushed aggregate has been found to have increased the compressive strength by 10 to 20 percent [1] [4]. The higher strength is attributed to the stronger bond development between cement paste and quarry dust aggregate.

\section{Significance of the study}

Use of quarry dust as fine aggregate of concrete has not been sufficiently understood. Influence of quarry dust on the shrinkage and workability of concrete is relatively unknown. There are also insufficient guidelines for the use of quarry dust in concrete. The main objective of this research is to find the guidelines for the use of quarry dust in structural concrete. The study also explores the use of fly ash in quarry dust concrete to improve the properties of concrete. To this end, effects of fly ash in reducing the initial water demand and the shrinkage of the concrete with quarry dust as fine aggregate is studied.

From the research investigation, it is found that the water demand in the quarry dust mixes are higher compared to standard sand mixes. It is also found that mixes with quarry dust as fine aggregate have always produced higher compressive strength compared to sand mixes at the same $\mathrm{W} / \mathrm{C}$ ratio. With detail investigation of different water/cement ratios and different workability, the study has allowed better understanding of the performance of concrete mixes with quarry dust as fine aggregate. The study has established that the shrinkages of quarry dust mixes are larger than the standard sand mixes for the same workability and W/C ratio. Furthermore, it is found that with the use of fly ash to replace $30 \%$ of cement can effectively reduce the shrinkage strains of quarry dust concrete to levels below shrinkage of sand mixes.

\section{Methodology}

To find whether the quarry dust satisfy the BS 882[5] grading requirement for fine aggregate, sieve analysis was done on six quarry dust samples collected from different crushers. Sieve analysis was also performed on river sand for comparison.

For the development of guidelines on the use of quarry dust in structural concrete, three different workabilities at three different $\mathrm{W} / \mathrm{C}$ ratios were studied. Altogether 27 mixes were studied with two series with quarry dust as fine aggregate and one with sand as find aggregate. Sand mix was done to compare the performance of the quarry dust mix. In one of

Table 1 Details of the mixes and their performances in this experimental program.

\begin{tabular}{|c|c|c|c|c|c|c|c|c|c|}
\hline & \multicolumn{9}{|c|}{ Characteristic compressive strength } \\
\hline & \multicolumn{3}{|c|}{20} & \multicolumn{3}{|c|}{30} & \multicolumn{3}{|c|}{50} \\
\hline $\begin{array}{c}\text { Type of Fine } \\
\text { Aggre. } \\
\text { Workability }\end{array}$ & Sand & $\begin{array}{c}\text { Quarry } \\
\text { dust }\end{array}$ & $\begin{array}{c}\text { Fly ash } \\
\text { Quarry } \\
\text { dust }\end{array}$ & Sand & $\begin{array}{c}\text { Quarry } \\
\text { dust }\end{array}$ & $\begin{array}{c}\text { Fly ash } \\
\text { Quarry } \\
\text { dust }\end{array}$ & Sand & $\begin{array}{c}\text { Quarry } \\
\text { dust }\end{array}$ & $\begin{array}{c}\text { Fly ash } \\
\text { Quarry } \\
\text { dust }\end{array}$ \\
\hline $\begin{array}{l}(10-30) \\
20 \mathrm{~mm}\end{array}$ & 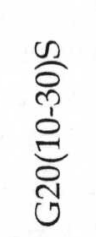 & 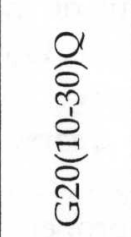 & 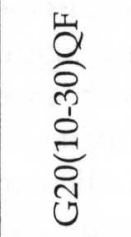 & $\begin{array}{l}0 \\
0 \\
0 \\
0 \\
0 \\
0 \\
0 \\
0 \\
0\end{array}$ & $\begin{array}{l}\alpha \\
\stackrel{\alpha}{0} \\
0 \\
0 \\
\stackrel{0}{0} \\
0 \\
0\end{array}$ & 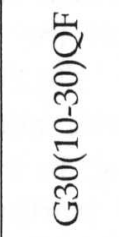 & 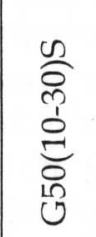 & $\begin{array}{l}0 \\
0 \\
0 \\
0 \\
0 \\
0 \\
0 \\
10 \\
0\end{array}$ & 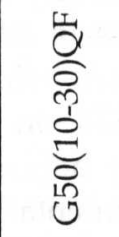 \\
\hline $\begin{array}{l}(30-60) \\
45 \mathrm{~mm}\end{array}$ & 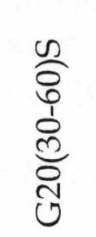 & 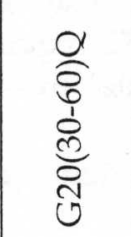 & 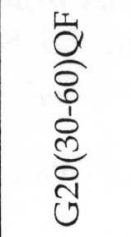 & $\begin{array}{l}0 \\
0 \\
0 \\
0 \\
1 \\
0 \\
0 \\
0 \\
0\end{array}$ & $\begin{array}{l}0 \\
0 \\
0 \\
0 \\
0 \\
0 \\
0 \\
0 \\
0 \\
0\end{array}$ & 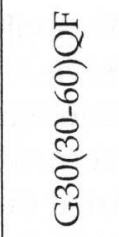 & $\begin{array}{l}0 \\
0 \\
0 \\
0 \\
0 \\
0 \\
0 \\
10 \\
0\end{array}$ & $\begin{array}{l}0 \\
0 \\
0 \\
0 \\
0 \\
0 \\
0 \\
10 \\
0 \\
0\end{array}$ & $\begin{array}{l}\frac{1}{0} \\
0 \\
0 \\
0 \\
1 \\
0 \\
0 \\
0 \\
0 \\
0\end{array}$ \\
\hline $\begin{array}{l}(60-180) \\
120 \mathrm{~mm}\end{array}$ & 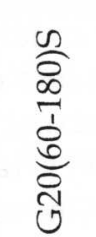 & 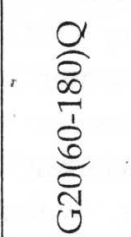 & 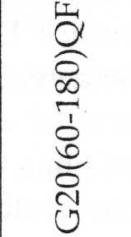 & \begin{tabular}{l}
0 \\
0 \\
0 \\
\multirow{1}{1}{} \\
0 \\
0 \\
0 \\
0 \\
0 \\
0
\end{tabular} & $\begin{array}{l}a \\
\partial \\
0 \\
1 \\
0 \\
0 \\
0 \\
0 \\
0 \\
0\end{array}$ & 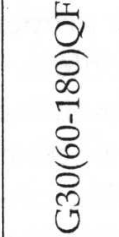 & $\begin{array}{l}0 \\
2 \\
\infty \\
1 \\
0 \\
0 \\
0 \\
10 \\
0\end{array}$ & $\begin{array}{l}\alpha \\
0 \\
\infty \\
1 \\
1 \\
0 \\
0 \\
0 \\
13 \\
0\end{array}$ & $\begin{array}{l}1 \\
0 \\
0 \\
\infty \\
-1 \\
0 \\
0 \\
0 \\
0 \\
0 \\
0\end{array}$ \\
\hline
\end{tabular}


the two quarry dust mixes, $30 \%$ of cement was replaced by equivalent binder content of fly ash with appropriate cement replacing binder ratio recommended in the British method of mix selection [6]. Table 1 shows all the mixes studied in the experimental investigation, with names given to identify the mixes according to its strength, workability and the type of the fine aggregate. For example a mix with strength of $20 \mathrm{MPa}(\mathrm{G} 20)$, workability $10-30 \mathrm{~mm}(10-30)$ and with sand (S) as fine aggregate gets the name G20(10-30)S. Three $\mathrm{W} / \mathrm{C}$ ratios relating to concrete strength 20,30 and $50 \mathrm{MPa}$ and three workability ranges $10-30,30-60$ and $60-120$ were selected for the study. First, mix proportions were derived according to the guidelines of British method of mix selection with sand as the fine aggregate [6]. As performance of quarry dust is compared with sand mixes, same mix proportions were used for quarry dust mixes. In all of the mixes Holcim brand Portland lime stone cement (PLC) (SLS 1253:2003)[7]][9] was used as the binder. PLC is different from OPC cement in its content of cementation compounds (Clinker). PLC requires containing minimum of $75 \%$ of cementations material compared to the minimum $95 \%$ of cementation compounds required in OPC cement (SLS 107: Part I :2002)[8][9].

It is difficult to select mix proportion to achieve certain compressive strength without reasonable number of trial mixes, tested at 28 days. Therefore, the selections of $\mathrm{mix}$ proportions for different strength grades were done assuming that, the water/cement (W/C) ratio according to the British method mix selection [6] would ensure required strength. Workability of concrete mix, which is normally expressed as the reduction in the height of standard slump cone (see Fig.1), mainly depends on the water content and can be readily adjusted during mixing. In the current experimental investigation, starting water content for a mix was initially decided based on the British method of mix selection[6] for the required slump and was then revised based on the resulted slump, until the required slump is achieved within $\pm 10 \mathrm{~mm}$ accuracy. When different water contents were tried out, content of cement of the mix was found by keeping the W/C ratio constant. Aggregate proportions, for adjusted cement and water content, was then decided based on the remaining weight requirement for a unit volume of concrete, with density of fresh concrete decided based on the water content and specific gravity of the aggregate according to the British method of mix selection [6].

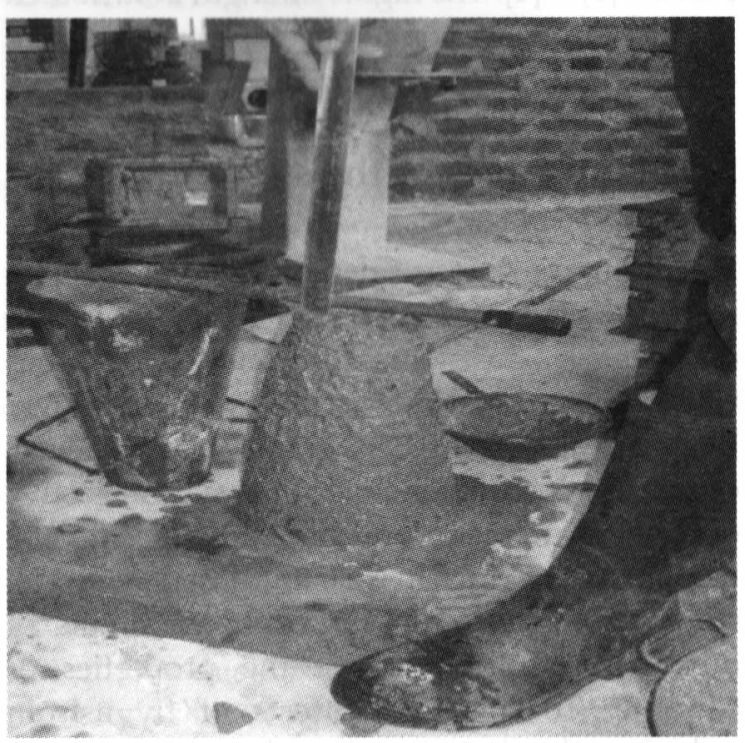

Fig. 1: Testing slump of fresh concrete

\section{Results and Discussion}

\subsection{Particle size distribution of the quarry dust}

Fig. 3 shows the gradation curves (particle size distribution curves) of quarry dust samples drawn from six quarries and river sand sample, compared with lower and upper bound of BS 882 recommendations for particle size distribution for fine aggregate of concrete [5]. Quarry dust samples from different sources had similar distribution to one another. Quarry dust has high amount of fines and high percentage of coarse material compared with sand. Most of the quarry dust samples satisfied the BS 882 requirement of the particle size distribution of fine aggregate. However there were few samples with excessive coarse content. This is due to mixing of quarry dust with other aggregates, particularly chips, and should be able to avoid easily by proper sieving at the source. Quarry dust from "Hapugala quarry" that conforms to the BS 882 requirement was selected for the experimental investigation.

\subsection{Water demand of the mix}

Determination of water absorption for Saturated Surface Dry (SSD) condition of aggregate and the actual water content of the aggregate at the time of concrete mixing is very important to maintain accurate $\mathrm{W} / \mathrm{C}$ ratio of the mix. It is the free water, water in excess of the amount 


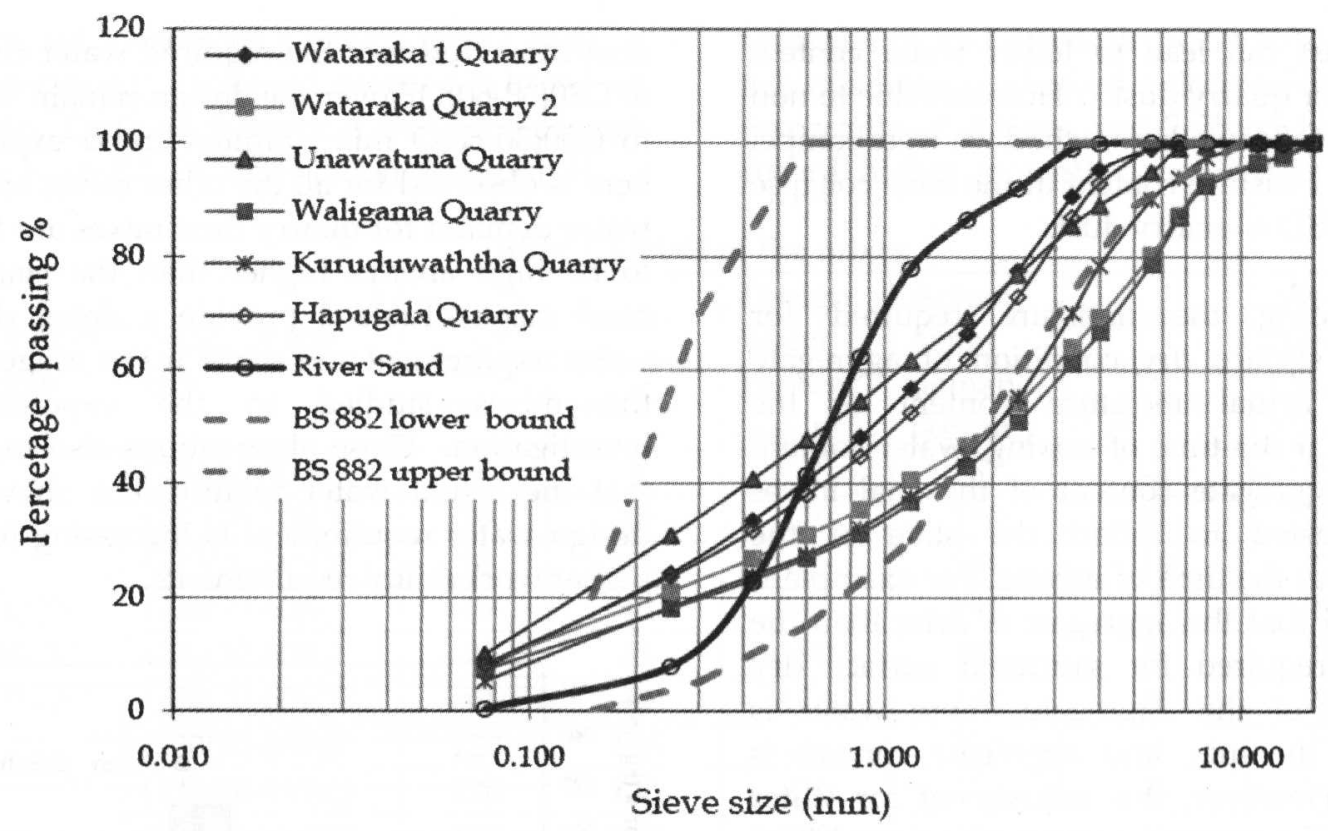

Fig. 2: Particle size distribution of quarry dust collected from different sources

required to bring the aggregate to SSD condition, which is available for hydration of cement and therefore the strength of concrete. Determination of moisture absorption for SSD condition of fine aggregate is done using the stability of the standard cone described in BS 812[10]. Fig. 3 show stable cone with moisture content of sand above the SSD condition. In this method moisture content for SSD is said to have achieved when the moisture content of the mix is inadequate to hold the fine aggregate particles together and the cone collapses with no distinguishable boundaries to identify it with the original shape of the cone [10].

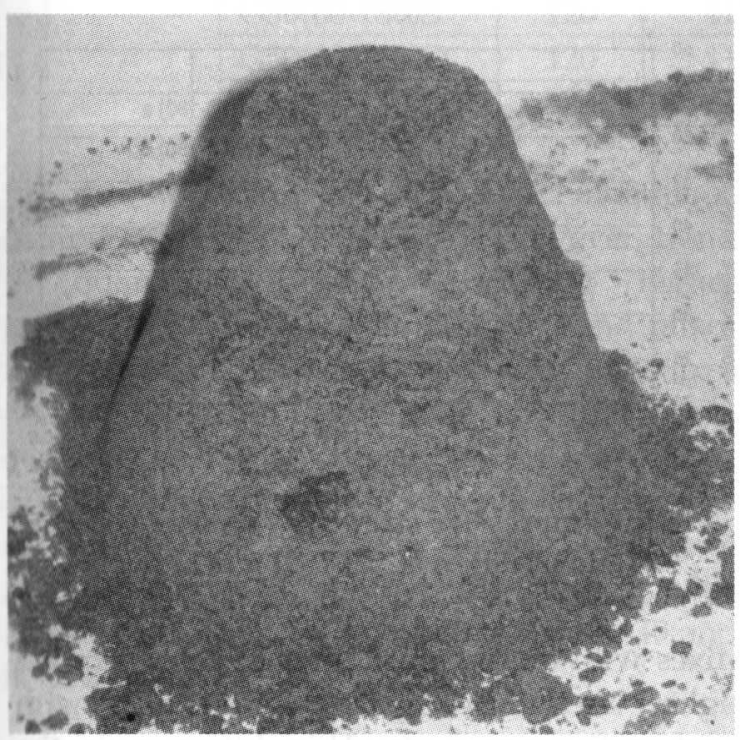

Fig. 3: Determination of SSD of fine aggregate

As coarse aggregate is sufficiently large, quite a different technique is adopted to find its moisture absorption for saturated surface dry condition. First samples were thoroughly soaked in water. Soaked aggregate is then mopped with cotton waste to achieve saturated surface dry condition of coarse aggregate. The moisture absorption for saturated surface dry condition of aggregate is then found by the difference in the weight of a sample drawn at SSD condition and oven dry weight of the same sample. SSD of aggregates are then expressed with respect oven dry weight of the sample. In the experimental investigation moisture absorption for SSD conditions of the different aggregates was found to be $1.37 \%$ for sand $0.5 \%$ for quarry dust and $0.87 \%$ for coarse aggregate. Quarry dust is expected to have more water demand than sand for saturated surface dry conditions and due to coarse surface texture and higher area of wetting required due to higher fine particle content. Lesser water demand recorded for quarry dust may be due to the testing method, which relied on the instability of the standard cone to determine the water requirement for saturated surface dry conditions of quarry dust. Stability of sand depends largely on the cohesion between the particles due to moisture held on the surface of the sand, and hence moisture content at the cone collapse is a reasonably good estimate for the SSD condition of sand. However, this is not the case for quarry dust. Angular shape and rough surface texture of quarry dust relies more on the friction between the particle than the cohesion for the stability of the cone and unlikely to have collapsed immediately after the exhaustion of surface water. Therefore the use of the same method to determine the SSD conditions of 
quarry dust can lead to lower water content recorded for quarry dust. However due to non availability of any other method we were compel to use the moisture content at the cone collapse to be the SSD of quarry dust.

After finding the moisture required for saturated surface dry condition of aggregate and the actual moisture content of the aggregate at the time of mixing, water content and the aggregate content of the trial mixes were adjusted to reflect the state of the aggregate at the time of mixing. For example if it is found that the aggregate is drier than the moisture required for saturated surface dry conditions of the aggregate, more water is added to the mix, and aggregate content is reduced. However, this adjustment for water content and aggregate content was done based on the natural moisture content of the aggregate determined one day before the actual mixing. To make sure that the aggregate used in the mix is in the same state of the aggregate tested for actual moisture content, sufficient aggregate for the mix was drawn from the pile simultaneously with the extraction of the sample and kept in a seal container. This is done to make sure that the adjustment to aggregate content and water content is done based on the test sample reflect same conditions of the aggregate being used for mixing.

Fig. 4 is a plot of design water content and the actual water content for $40 \mathrm{~mm}$ slump of Grade 30 concrete for all mixes; sand mix, quarry dust mix, quarry dust with fly ash mix. Design water content for the sand mix is taken from the British method of mix selection. As the quarry dust is studied with respect to sand and finding the appropriate water content for quarry dust mixes is one of the objectives of the study, same design water content used for the sand mixes is used for the comparison of quarry dust mixes. However different design water content is used for quarry dust fly ash mixes as the reduction of water demand for mixes has already being identified in the British method of mix selection. Therefore reduced water requirement after adjustment due to use of fly ash in the mix is taken as the design water requirement of the fly ash quarry dust mix. According to Fig. 4 actual content of water required for standard sand mix is found less than the design (see bar chart pertaining to G30(30-60)S ). Use of quarry dust has increased the water requirement by approximately $20 \mathrm{~kg}$ per $\mathrm{m}^{3}$. It is also seen that fly ash has reduced the water content of quarry dust mix. However the required water content of G30(30-60)QF over the design remain similar to G30(30-60)Q mix. Similar trend explained here is observed for all the other mixes and the water demand for quarry dust mixes are found to be high always higher than the standard sand mixes. Table 2 provide a detail design water requirement and actual water usage of all the mixes studied in the experimental investigation. Close observations also indicate that the actual water requirement above the design water requirement is increasing for the higher workability requirements.

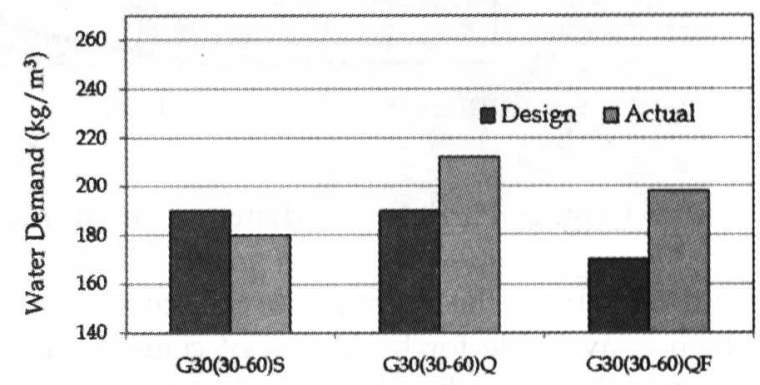

Fig. 4: Design and actual water demand

\subsection{Compressive strength of concrete}

Fig. 5 shows 28 days compressive strength vs. $\mathrm{W} / \mathrm{C}$ ratio for the three types of mixes for the slump of $120 \pm 10 \mathrm{~mm}((60-180) \mathrm{mm}$ slump range). Fig. 5 also includes the reference design curve in the British method of mix selection used in the derivation of the $\mathrm{W} / \mathrm{C}$ ratio of the mixes.

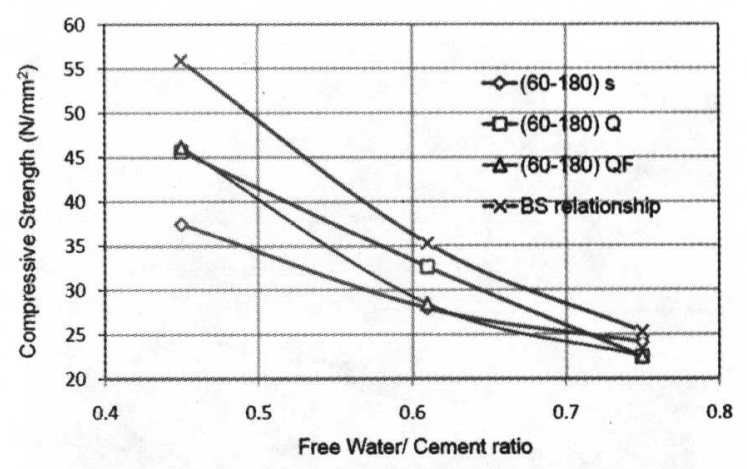

Fig.5: Compressive strength Vs. water/cement ratio of mixes at $(60-180) \mathrm{mm}$ slump

Mixes with quarry dust as aggregate recorded higher strength compared with mixęs with sand as fine aggregate. This difference in the strength became significant at lower W/C ratios while it is found insignificant at higher $\mathrm{W} / \mathrm{C}$ ratios. Overall reductions of strength below the design curve are attributed to the use 
of Portland Limestone Cement (PLC) type in the experiments. Designed curves are based on Ordinary Portland Cement (OPC) type cement with at least $95 \%$ in cementation compounds. workability and strength ((G50 (10-30) S). Fly ash mix initially showed a decrease in strength (especially at 3 days and 7 days) before they record higher strength compared to the sand

Table 2 Detail of the mixes

\begin{tabular}{|c|c|c|c|c|c|c|c|}
\hline $\begin{array}{l}\text { Concrete } \\
\text { grade }\end{array}$ & $\begin{array}{l}\text { Name of the } \\
\text { mix }\end{array}$ & $\begin{array}{l}\text { Design } \\
\text { slump } \\
(\mathrm{mm})\end{array}$ & $\begin{array}{l}\text { Slump } \\
\text { achieved } \\
(\mathrm{mm})\end{array}$ & $\begin{array}{l}\text { Design } \\
\text { water } \\
\text { content } \\
\mathrm{kg} / \mathrm{m}^{3} \text { ) }\end{array}$ & $\begin{array}{l}\text { Actual } \\
\text { water } \\
\text { demand } \\
\left(\mathrm{kg} / \mathrm{m}^{3}\right)\end{array}$ & $\begin{array}{l}\text { Excess } \\
\text { water } \\
\left(\mathrm{kg} / \mathrm{m}^{3}\right)\end{array}$ & $\begin{array}{l}\text { Strength } \\
\text { Achieved } \\
\text { (28 days) } \\
\mathrm{N} / \mathrm{mm}^{2}\end{array}$ \\
\hline \multirow{9}{*}{$\begin{array}{c}\text { G20 } \\
W / C \\
0.75\end{array}$} & G20(10-30)S & 10 & 8 & 170 & 167 & -3 & 24.29 \\
\hline & G20(10-30)Q & 10 & 10 & 170 & 170 & 0 & 25.21 \\
\hline & G20(10-30)QF & 10 & 12 & 155 & 184 & 19 & 26.86 \\
\hline & G20(30-60)S & 40 & 40 & 190 & 194 & 4 & 23.86 \\
\hline & G20(30-60)Q & 40 & 43 & 190 & 195 & 5 & 23.81 \\
\hline & G20(30-60)QF & 40 & 40 & 170 & 208 & 38 & 21.95 \\
\hline & G20(60-180)S & 120 & 125 & 210 & 212 & 2 & 24.12 \\
\hline & G20(60-180)Q & 120 & 120 & 210 & 237 & 27 & 23.48 \\
\hline & G2060-180)QF & 120 & 115 & 190 & 227 & 37 & 23.75 \\
\hline \multirow{9}{*}{$\begin{array}{c}\text { G30 } \\
W / C \\
0.65\end{array}$} & G30(10-30)S & 10 & 10 & 170 & 161 & -9 & 31.46 \\
\hline & G30(10-30)Q & 10 & 10 & 170 & 192 & 22 & 35.13 \\
\hline & G30(10-30)QF & 10 & 12 & 155 & 184 & 29 & 31.97 \\
\hline & G30(30-60)S & 40 & 38 & 190 & 180 & -10 & 26.84 \\
\hline & G30(30-60)Q & 40 & 35 & 190 & 212 & 22 & 33.63 \\
\hline & G30(30-60)QF & 40 & 38 & 170 & 198 & 28 & 30.85 \\
\hline & G30(60-180)S & 120 & 115 & 210 & 205 & -5 & 27.96 \\
\hline & G30(60-180)Q & 120 & 115 & 210 & 239 & 29 & 32.62 \\
\hline & G30(60-180)QF & 120 & 123 & 190 & 237 & 47 & 28.45 \\
\hline \multirow{9}{*}{$\begin{array}{c}\text { G50 } \\
\text { W/C } \\
0.45\end{array}$} & G50(10-30)S & 10 & 7 & 170 & 162 & -8 & 42.53 \\
\hline & G50(10-30)Q & 10 & 8 & 170 & 183 & 13 & 50.66 \\
\hline & G50(10-30)QF & 10 & 12 & 155 & 193 & 38 & 51.98 \\
\hline & G50(30-60)S & 40 & 40 & 190 & 195 & 5 & 40.66 \\
\hline & G50(30-60)Q & 40 & 3 & 190 & 226 & 36 & 43.61 \\
\hline & G50(30-60)QF & 40 & 43 & 170 & 210 & 40 & 53.11 \\
\hline & G50(60-180)S & 120 & 115 & 210 & 223 & 13 & 37.43 \\
\hline & G50(60-180)Q & 120 & 118 & 210 & 255 & 45 & 45.63 \\
\hline & G50(60-180)QF & 120 & 118 & 190 & 256 & 66 & 46.13 \\
\hline
\end{tabular}

PLC has approximately $20 \%$ less cementitious compounds compared to OPC. However, trend of quarry dust mixes reaching higher compressive strength compared to sand mixes is consistently recorded in most of the mixes (see the full detail in the Table 2 column 8). On average quarry dust mixes recorded approximately $10 \%$ more strength compared to sand mixes (see table 2 for details). Difference in the recorded strength is also found to be higher for higher grade concrete, Grade 30 and 50 in particular.

Fig. 6 shows the strength development of quarry dust mixes (G50 (10-30) Q and G50 (1030) QF) expressed as increase or decrease of strength compared to strength of same age sand mix as datum with the same designed mixes. Fly ash is pozzolanic material and the delay may be mainly due to delayed reaction of fly ash [11] [14].

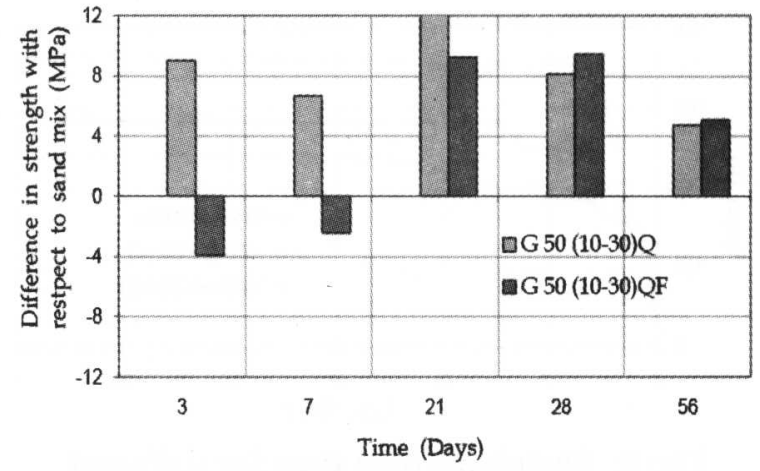

Fig. 6: Strength development of quarry dust mixes compared with control mix as datum. 


\subsection{Shrinkage of concrete}

Shrinkage of quarry dust concrete is another important property looked at in this experiential study. Higher use of water in quarry dust mixes to achieve same designed workability not only require increase in water but also increase in the cement content to maintain the same $\mathrm{W} / \mathrm{C}$ ratio. Both of which can increase the shrinkage of concrete. There is also a possibility that the aggregate, especially the quarry dust might absorb some water from the mix and hence cause further shrinkage. Shrinkage measurement was done using a multi-position strain gauge [15]. During the measurement specimens were kept similar to actual site conditions, wrapped with gunny bags and watered daily. This procedure is expected to reduce the drying shrinkage to a greater degree though there is no guaranty that, this curing regime will eliminate the drying shrinkage completely. As all the specimens underwent same conditions and simulate closely with the actual site curing, measured shrinkage is expected to be more realistic representation of actual shrinkage. Fig. 7 shows the arrangement of measuring shrinkage along with typical shrinkage results for Grade 30 concrete with a slump of $(60-180) \mathrm{mm}$.
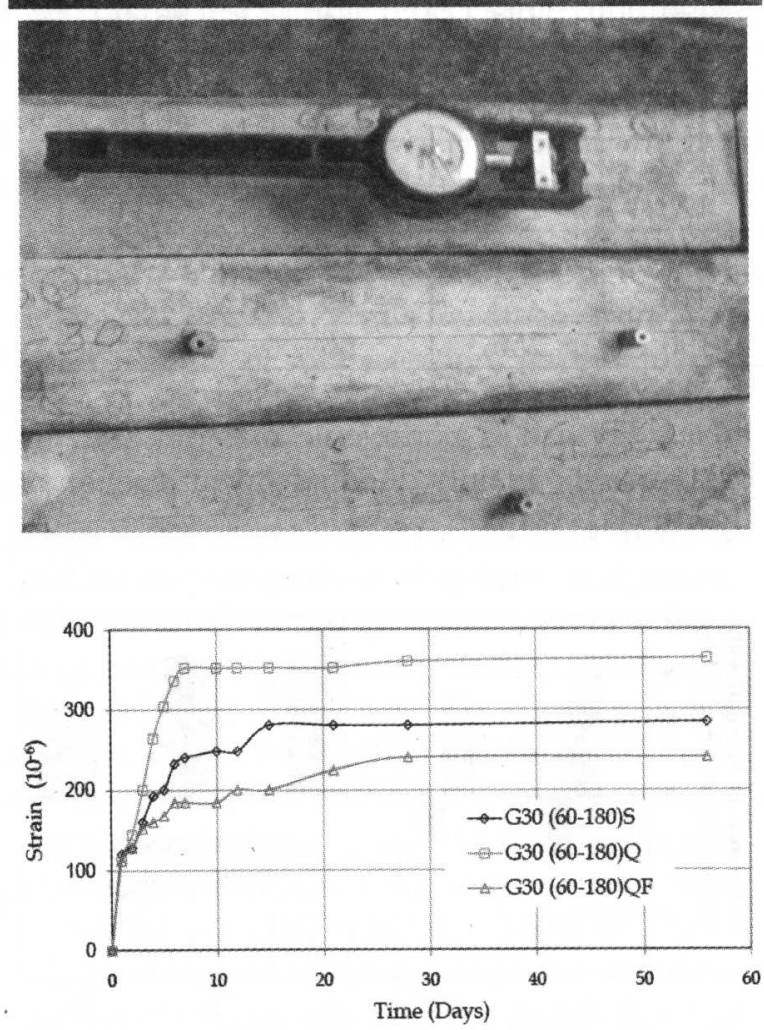

Fig. 8: Shrinkage over time for different mixes.
Although the concrete strain due to shrinkage is within the acceptable limits for all the types of mixes [16] (Clause 3.4.6.7 off BS8110 Part I and Section 7 of BS8110 Part 2), quarry dust mixes clearly have higher shrinkage compared with corresponding sand mixes. However, the use of fly ash in the quarry dust mixes has reduced the shrinkage of concrete (see for example shrinkage strain of quarry dust fly ash concrete in Fig. 7). This may have been due to the reduction of the water demand and delayed hydration reaction of fly ash.

\section{Conclusions}

Quarry dust concrete has consistently produced higher compressive strength compared with sand mixes. Quarry dust mixes always required higher water contents to achieve the same workability of sand mixes. Increase of water demand of quarry dust mixes may have caused by net increase of aggregate surfaces due to increased fineness of quarry dust particles and the difficulty in compacting coarse angular shape aggregates. In addition, use of the same method of sand (the stability of the cone) in determining the SSD of quarry dust can underestimate the actual water requirement of quarry dust. This underestimation of water can be reflected as higher water requirement when quarry dust is used as the aggregate of the concrete mix.

Use of fly ash has reduced the water demand in certain mixes. However, it is found that the water demand is still in excess of the design and the reduction, if any, is mainly attributed to the increase of workability due to use of fly ash rather than real decrease of water demand of quarry dust mixes. Although it is within the limits prescribed in BS 8110, quarry dust has recorded higher shrinkage compared with sand mixes. However, use of fly ash has been found very effective in bringing down the excessive shrinkage strain of quarry dust concrete mixes. Quarry dust mixes always had higher compressive strength and always required high water content to achieve the same workability of sand mixes. Overall results of the experimental study indicate that quarry dust is a viable alternative for fine aggregate of concrete and that fly ash can enhance the properties of quarry dust mixes. 


\section{References}

1. Ilanganova. R, Mahendran N., Nagmanib, k.,(2008)"Strength and durability properties of concrete containing quarry rock dust as fine aggregate", APRN Journal of Engineering and applied sciences, Vol. 3, No. 5, 20-26 pp.

2. Ilangove R, Nagamani K (2006), Application of Quarry rock dust as fine aggregate in concrete construction", Journal of construction management, Vol. XXI, No. 4.

3. Ho. D.W.S, Sheinn A.M.M., Ng C.C, Tam C.T., "The use of quarry dust for SCC applications", Cement and concrete research, Volume 32, Issue 4, pp. $505-5111$

4. Gambhir M.L.G, (1999), Concrete Technology, second edition, 24-30 pp

5. BS 882 (2002), "Specification for aggregate from natural sources for concrete", British standard institute, London.

6. Teychenne D. C., Franklin R.E., Erntroy H.C., (1975), "Design of normal concrete mixes" Department of the environment, 1-40 pp.

7. SLS 1253:2003, Specification for Portland Lime Stone Cement, Sri Lankan Standard Institute. Sri Lankan Standard Institute, No. 17, Victoria Place Colombo 8

8. SLS 107: Part 2: 2002,"Specifcation for Ordinary Portland Cement, Sri Lankan Standard Institute, No. 17, Victoria Place Colombo 8

9. BS8500-1:2006, "Method of specifying and guidance to specifier", British Standard Institute, London

10. BS 812: Part 2: 1975 (1975), "Testing aggregate method for determination of physical properties", British Standard Institute,London.

11. Neville. A.M., (1995), "Properties of concrete", pp 84,139,649-661

12. Dias W.P.S, Nanayakkara S.M.A., Ekneligoda T.C., (2003), "Performance of concrete mixes with OPC-PFA blends", Magazine of concrete research,.

13. http://useit.umaine.edu/materials/ flyash/ general_information.htm

14. Www.fhwa.dot.gov/materialsgrp/flyash,

15. BS 812-120:1989, Testing aggregate Part 120: Methods for testing and classifying drying shrinkage of aggregate in concrete

16. BS 8110: Part 2: 1997 (2002), "Structural use of concrete", British Standard Institute. 